\title{
Interview with W. Fitzhugh Brundage, Summer 2019
}

\author{
William D. Carrigan ${ }^{*}$ and Clive Webb ${ }^{* *}$ \\ ${ }^{*}$ Corresponding author. Rowan University. E-mail: carrigan@rowan.edu \\ ${ }^{* *}$ Corresponding author. University of Sussex. E-mail: c.j.webb@sussex.ac.uk
}

Keywords: lynching; mob violence; racial violence; W. J. Cash

To understand better how a young graduate student at Harvard decided to take on such an unusual project, we interviewed W. Fitzhugh Brundage in the Summer of 2019. The exchange proved, so enlightening and compelling that we and the editors agreed it should be shared separately. It has been lightly edited.

William D. Carrigan (WDC) and Clive Webb (CW): First, when and why did you decide you wanted to become a historian?

W. Fitzhugh Brundage (WFB): It happened without a moment of conscious decision. I knew I wanted to get a $\mathrm{PhD}$ and teach when I went to college, but I was drawn equally to Anthropology and History. A few courses in Anthropology and Archaeology quickly revised my thinking, and, by my junior year, I knew that I was going to apply to graduate school in History. ${ }^{1}$

WDC and CW: When did you first become interested in studying lynching?

WFB: I knew literally nothing about lynching until my first year of graduate school. I took a hybrid undergraduate/graduate seminar taught by Alan Brinkley, and we read W. J. Cash's Mind of the South. ${ }^{2}$ I had read the book as an undergraduate (in a course taught by John Hope Franklin), but it didn't have much effect on me. But when I read it in my first year of graduate school, I took real umbrage to it. At the time I found Cash's arrogance and hubris-the MIND of the SOUTH!!!-offensive. So little of what he described resembled anything I was familiar with growing up in Virginia. (I didn't understand then that Cash only knew one portion of the South and I only knew another very atypical part of the South.) So, I decided that I would challenge Cash and that I would do so by disproving his interpretation of lynching. I honestly can't recall why I thought lynching was the best avenue by which to critique Cash, but it got me into newspapers in Virginia, Washington, D.C., and at Harvard and I quickly realized that not only was Cash's interpretation inadequate but so were all the other extant interpretations. So, while I had never intended to write my dissertation on lynching or 
southern history, I found the topic so rich that I decided I would linger on it, and, within a year, I had settled on it for my dissertation topic.

WDC and CW: Has your perspective on Cash changed over the years?

WFB: I "hated" Cash for years but now actually enjoy him for all of his failings, excesses, and other vices. The sheer audacity of the book inspires me. My initial response to his treatment of lynching was, I now think, a misreading of Cash. His portrait of lynching seemed overly pat to me and to have strong hints of the "southern white trash" analysis of lynching. But on rereading the book many times I have come to understand that Cash was somewhat more subtle than I recognized. I also think his "gyneolatry" discussion of rape and white womanhood is actually quite compelling. ${ }^{3}$

Finally, I think I was initially frustrated by his disjointed, scattered treatment of the phenomenon. In places I recall thinking that Cash was cramming lynching into some grand schema of the "southern mind." Now, decades later and after grappling with the challenges of fitting the messiness of the past into historical narratives, I have greater appreciation for the challenges that Cash or any author faces. So, in retrospect, I now recognize that Cash's treatment of lynching was probably the most thoughtful that one was going to find in print prior to the 1980s.

WDC and CW: What scholars who published before you were of particular influence and why?

WFB: Cash, of course, was the initial spark. But I quickly concluded that I would need to look elsewhere for inspiration. Within a year of deciding to delve into the topic Edward Ayers, Joel Williamson, and Bert Wyatt-Brown all published books that touched on lynching and convinced me that the topic was worthy of a dissertation. Although there wasn't much of a historiography on lynching to "draft behind," these books meant that there was some very fine scholarship on violence and power in the nineteenth-century South. Joel Williamson's Crucible of Race had a powerful effect on me. It is a sprawling and undisciplined work in some regards, but there are remarkable insights scattered throughout every chapter. Moreover, Williamson drew attention to the violence that saturated every aspect of late nineteenth-century southern life in a manner that still fires my imagination. Jacquelyn Hall's Revolt Against Chivalry also influenced me to understand where opposition to lynching arose in the white South and why white women played an outsized role. Finally, I drew inspiration from several anthropologists, especially Victor Turner and Stanley Tambiah. They helped me think about social ritual as fine-grained, complex, multivariant events. ${ }^{4}$

WDC and CW: What were some of your greatest research “discoveries" or breakthroughs?

WFB: I don't think there was a "discovery," per se. But I would like to think that my book underscored that lynching was worthy of very careful scrutiny and that it had far-reaching, contradictory effects on southern and American society. Let me put it another way. No one who writes a history of the New South, as [C. Vann] Woodward did in The Origins of the New South, will devote as little space to lynching as Woodward did. Woodward saw lynching as epiphenomenon worthy of a couple of pages. During the past twenty-five years that perspective has vanished from the scholarship. ${ }^{5}$ 
WDC and CW: What was the hardest thing about doing your research on the book?

WFB: Two things, one practical and one emotional. The practical issue was that I had to read literally tens of thousands of pages of microfilm because there were no indexes of microfilmed newspapers. I read every editorial page of the Atlanta Constitution for fifty years. That is a mind-numbing, headache inducing, soul-emptying experience. But there was really no alternative back then. The research that took me three years to complete can be done in a summer now that online search engines are readily available.

The emotional issue was a recurring but episodic horror. I confess that I did not meditate on the gruesome violence at the heart of my dissertation research every day. Instead, I would be working out some element of my emerging argument for days or weeks at a time and then, suddenly, some quote, detail in a document, headline, or other catalyst would prod me to recall that I was writing about horrific acts of degradation, torture, and violence. I never wanted to be callous about the people in my book, and so those moments were a periodic reminder that my topic wasn't just a historical riddle to be solved.

WDC and CW: Of the awards, congratulations, and positive reviews you received, which one was most gratifying to you?

WFB: Probably that you folks have organized this special issue. It is gratifying to know that this book is still of use to someone. While I may be a naturally shy person, I never wanted my ideas to be shy. I assume all of us in this profession hope that our ideas will be promiscuous and will find an audience in places that we never anticipated.

WDC and CW: Looking back after more than twenty-five years, what aspects of Lynching in the South make you most proud or stand the test of time best, etc.?

WFB: I think the general approach has stood the test of time. My thought when I wrote my dissertation was that longitudinal studies of lynching were needed; case studies certainly have their merits, but the phenomenon benefits from a historian's attention to change over time and context. I remain convinced that lynchings had complex origins that can be traced to both local and regional (national) sources. Likewise, I also believe that we historians have been adept at drawing attention to the political (broadly defined) and cultural context in which lynchings occurred. So I think of Lynching in the New South as a historical approach to a topic that had not been addressed (with any detail) by historians. I think the value of that general approach is demonstrated by both it and all the subsequent works that historians have written on lynching.

WDC and CW: How has the study of lynching changed over the last twenty-five years?

WFB: The change is striking. When I entered the profession and began giving conference papers, I had to work to identify people with whom I could organize panels. In those days it was me and George C. Wright. ${ }^{6}$ I routinely had to explain my interest in the topic to nonspecialists and even some fellow historians thought of the topic as a grisly curiosity. But by 2000, and especially after the Without Sanctuary exhibits in New York, Atlanta, and elsewhere, the study of lynching reached a critical mass. ${ }^{7}$ Perhaps because of the power (and horror) of the lynching images and the visual 
orientation of our age, lynching scholarship shifted heavily toward a focus on the cultural manifestations of the phenomenon, by which I mean the visual symbolism of lynching and the material culture associated with it, the aesthetic response to it (in literature, drama, the visual arts), etc. Another important development has been the "nationalization" of the study of lynching. When George and I studied lynching, we understandably focused on the region where lynching was most pervasive. We both knew that lynchings occurred elsewhere, but we had enough on our plates just trying to make sense of Kentucky, Georgia, and Virginia. Now, thanks to your work, Michael Pfeifer's work, and others, we now can discuss lynching as a national phenomenon and have a far better sense of who enjoyed freedom from the threat of lynching and who lived under threat of death. ${ }^{8}$

WDC and CW: What things would you change if you were to start the project now instead of in the 1980s?

WFB: Three things. First, in part because I thought the connection between paranoia about rape and its connection to lynching had been exhausted by Cash and others, I did not foreground the politics of gender and their relationship to lynching as I would now.

Second, I would emphasize more explicitly than I did that the power of lynching to terrorize was as much through discourse as through violence. More broadly, I was not as clear about the degree to which almost all of the written public record about lynching is a discourse carefully constructed by white southerners. Of course, there is a powerful counter-discourse fashioned by African Americans. But white southerners controlled the print media and wire services in the South so any study of lynching must engage with a carefully crafted white discourse. I understood this point in a general way, but I would now foreground it and linger on the ways in which the tropes of this discourse were sustained by newspaper reporting.

Finally, Elsa Barkley Brown took me to task, appropriately, for my discussion of racial violence against African American women. In a few paragraphs I attempted to address the glaring disparity in the distribution of lynchings by gender. In those passages I emphasized that few African American women were lynched by themselves; most African American women were lynched along with African American men who were the alleged target of the mob. My point was that whites perhaps tolerated behavior from women that they would not tolerate from African American men. Moreover, lynchings were often the culmination of cycles of escalating violence between African American men and white men. The problem with the argument in question is that I phrased it in a manner that suggested that African American women were less likely to be victims of "racial violence." My error is obvious. I meant lynching, but because of my vague word choice I erased the pervasive threat of white sexual violence and other forms of white violence against African American women. The passage remains a powerful reminder to me of the need for clarity and precision because readers will understandably read my prose as it is written, not how it sounded in my own head. ${ }^{9}$

WDC and CW: One final question. We have heard that the book manuscript went through some peculiar circumstances before publication. Can you reveal the story?

WFB: Here is the story of the manuscript. I was living in Canada and teaching at Queen's University when I finished my manuscript. Because I was not a fan of the service provided 
by Canada Post, I used to drive to Watertown, New York to mail packages. Well, I took my manuscript there, and the owner of the Mailboxes Plus there used recycled boxes to ship boxes by United Parcel Service. Her thought was that it saved customers money, and it recycled boxes. So, she used a box she had gotten from the local Blimpie's sub shop to ship my manuscript to August Meier at Kent State University. I sent it in early August and promptly received a nice note from Auggie's secretary thanking me for the package on behalf of Auggie and explaining that he was in India and would return in several weeks. I heard nothing from Auggie when he returned, but I thought nothing of it. I knew nothing about the production of a book manuscript, and I assumed he was busy. Eventually, in about November I got a note from Auggie (all of this transpired before e-mail was routine) asking me when I would submit my manuscript. I was puzzled since I had submitted my manuscript months prior and I knew that his secretary had received it. So, I immediately called his secretary and asked her about the package I had sent in August. On the other end of the phone line I heard a gasp and then a loud laugh. It turns out that she had thought I had sent Auggie a submarine sandwich from Blimpie's (why she thought this still baffles me) and so she had put it in the refrigerator in the department at Kent State. Auggie apparently had never had an urge to eat my presumed gift so my manuscript had been sitting in the refrigerator for four months. It was rescued from cold storage and put into production. So my book took at least five months longer than expected to make it to press through no fault of my own.

\section{Notes}

1 Professor Brundage attended the University of Chicago as an undergraduate, graduating in 1981.

2 In 1941, W. J. Cash's provocative and monumental work, The Mind of the New South, appeared in print to great acclaim. It remained assigned reading in undergraduate and graduate courses on race relations and the American South throughout the rest of the century and even into the twenty-first century. Cash's ambitious and wide-ranging analysis used history and contemporary data to provide a sweeping portrait of white southern culture. One of the areas that he discussed in detail throughout the book was the history and ongoing status of lynching in the South. Cash argued that lynching arose out of the American South's individualism and existed in full force before the Civil War and before the majority of victims were African Americans. It developed and persisted not only out of habit, but also because the act grew over time to be seen as morally right and to have ritualistic value because mob violence, especially of African Americans, was widely supported by all classes in the local community. Cash also noted that lynching and private violence both increased because the general "wrongness of violence" had been blunted by Republican control during Reconstruction during which, Cash claimed, the courts could not be trusted to treat non-Republicans fairly. Cash emphasized the rise of private violence against African Americans and the emergence of a class of sadists whose actions only rarely triggered critiques by the white elite who largely accepted justifications that the victim had violated southern mores toward white men and, especially, white women. Cash, however, argued that these men who sought the "pleasure of violence" did not by themselves produce lynchings. Cash also cited lynching statistics to argue that the late nineteenth century had been the greatest period of white hatred of African Americans. He contended that the white elite "recovered" and rejected participation in lynching beginning in the early twentieth century, but also conceded that the community leaders did little to restrain mob violence and could be blamed for the lack of police and judicial investigation of lynching. While Cash seems to suggest that the white poor were the key instigators of lynching, he admits that due to their failure to prosecute mob leaders the "major share of the responsibility" for "the persistence of lynching in the region down to the present" surely "rests squarely on the shoulders of the master classes." Cash also made much of the fact that lynching persisted in rural parts of the South and was largely disappearing from the zones of "town and factory and commerce" due to the economic incentives in each place (and not a disparity in levels of racial animus toward African Americans). See W. J. Cash, The Mind of the South (New York: Knopf, 1941), $45,121,308,310-11,316$. 
3 The "Yankee must be answered by proclaiming from the housetops that Southern Virtue, so far from being inferior, was superior, not alone to the North's but to any on earth, and adducing Southern Womanhood in proof. The upshot, in this land of spreading notions of chivalry, was downright gyneolatry. She was the South's Palladium, this Southern woman ... was the pitiful Mother of God. Merely to mention her was to send strong men into tears-or shouts. There was hardly a sermon that did not begin and end with tributes in her honor, hardly a brave speech that did not open and close with the clashing of shields and the flourishing of swords for her glory." Cash, The Mind of the South, 90.

4 The works to which Professor Brundage is referring are the following: Bertram Wyatt-Brown, Southern Honor: Ethics and Behavior in the Old South (New York: Oxford University Press, 1982); Joel Williamson, The Crucible of Race: Black-White Relations in the American South since Emancipation (New York: Oxford University Press, 1984); Jacquelyn Dowd Hall, Revolt Against Chivalry: Jessie Daniel Ames and the Women's Campaign Against Lynching (Columbia: New York University Press, 1979). Victor Turner was a British anthropologist whose works often focused on ritual and symbol. One of his most famous books was the reprinted lecture series, The Ritual Process: Structure and Anti-Structure (New York: Transaction Publishers, 1969, reprinted 1995). Stanley Tambiah was a Sri Lankan-born anthropologist who was a longtime professor at Harvard University. His many contributions to the academy included prizewinning analyses of ethnic violence and competing religious identities published in Levelling Crowds: Ethnonationalist Conflicts and Collective Violence in South Asia (Berkeley: University of California Press, 1996).

5 C. Vann Woodward, Origins of the New South, 1877-1913 (Baton Rouge: Louisiana State University Press, 1951, reprinted 1971).

6 George C. Wright, Racial Violence in Kentucky, 1865-1940: Lynchings, Mob Rule, and "Legal Lynchings" (Baton Rouge: Louisiana State University Press, 1990).

7 James Allen, ed., Without Sanctuary: Lynching Photography in America (Santa Fe, New Mexico: Twin Palm Publishers, 2000).

8 William D. Carrigan and Clive Webb, Forgotten Dead: Mob Violence against Mexicans in the United States, 1848-1928 (New York: Oxford University Press, 2013); Michael Pfeifer, Rough Justice: Lynching and American Society, 1874-1947 (Urbana: University of Illinois Press, 2004); Michael Pfeifer, The Roots of Rough Justice: Origins of American Lynching (Urbana: University of Illinois Press, 2011).

9 See page 112 in Elsa Barkley Brown, "Negotiating and Transforming the Public Sphere: African American Political Life in the Transition from Slavery to Freedom," Public Culture 7 (1994): 107-46.

W. Fitzhugh Brundage has been the William B. Umstead Professor at the University of North Carolina at Chapel Hill since 2002. He previously taught at the University of Florida and Queen's University (Ontario).

William D. Carrigan is Professor of History at Rowan University. He earned his BA at the University of Texas at Austin and his $\mathrm{PhD}$ from Emory University. He is the author or editor of numerous scholarly articles and four books, including The Making of a Lynching Culture: Violence and Vigilantism in Central Texas, 1836-1916 (University of Illinois Press, 2004). Since 1995, he has been collaborating with Clive Webb and studying the lynching of Mexicans in the United States. With the support of grants and fellowships from numerous institutions, they have published eight articles or chapters and one monograph on the subject, Forgotten Dead: Mob Violence against Mexicans in the United States, 1848-1928 (Oxford University Press, 2013).

Clive Webb is Professor of Modern American History at the University of Sussex. He is the author most recently, with William D. Carrigan, of Forgotten Dead: Mob Violence against Mexicans in the United States 1848-1928 (Oxford University Press, 2013).

Cite this article: William D. Carrigan and Clive Webb, "Interview with W. Fitzhugh Brundage, Summer 2019," The Journal of the Gilded Age and Progressive Era 20, 168-173. https://doi.org/10.1017/ S1537781420000626 